Saudi Journal of Business and Management Studies Abbreviated Key Title: Saudi J Bus Manag Stud ISSN 2415-6663 (Print) |ISSN 2415-6671 (Online) Scholars Middle East Publishers, Dubai, United Arab Emirates Journal homepage: https://saudijournals.com

\title{
Characteristics of Top Management, Good Corporate Governance, and Earnings Quality (A Study of State-Owned Entreprises in Indonesia 2016- 2018)
}

Theresia Olivia*, Erna Setiany

Master Program in Accounting at Mercubuana University Jakarta Indonesia

\author{
DOI: $\underline{10.36348 / \text { sjbms.2021.v06i04.004 }}$ \\ | Received: 16.03.2021 | Accepted: 21.04.2021 | Published: 30.04.2021 \\ *Corresponding author: Theresia Olivia
}

\section{Abstract}

The purpose of this study is to provide empirical evidence regarding the influence of management characteristics and GCG on earnings quality, in the midst of the urgency of earnings quality information that is prone to conflict of interest, especially in state-owned companies today. This research is a quantitative research where the population is all stateowned companies in Indonesia which are listed on the website of State-Owned Entreprises (SOE) in 2016-2018. The sampling technique used a purposive sampling, and obtained 67 companies that meet the standards. The technique of collecting data is by taking information from the company's annual report so that the data source used is secondary data. The analysis method used is Eviews. The results showed that educational background, gender, and GCG had a positive effect on earnings quality. Meanwhile, tenure has a negative effect on earnings quality.

Keywords: Tenure, Educational Background, Gender, GCG, Earnings Quality.

Copyright (C) 2021 The Author(s): This is an open-access article distributed under the terms of the Creative Commons Attribution 4.0 International License (CC BY-NC 4.0) which permits unrestricted use, distribution, and reproduction in any medium for non-commercial use provided the original author and source are credited.

\section{INTRODUCTION}

One form of management accountability to stakeholders, especially investors, is information on earnings in financial reports that are presented reliably and relevant. Earnings information is very important in order to show management performance and have an impact on the decision making of investors and other stakeholders [1]. Incorrect information can be misleading and lead to inaccuracy in decision making, and it is possible that the company will be distrusted by investors. Therefore, users of financial statements need quality earnings information, namely earnings reported by companies that are reliable and have benefits in decision making (relevant).

So important is the value of earnings in the financial statements that many management actions attempt to carry out earnings management practices. The higher the earnings management practice, the lower the earnings quality. In measuring the quality of earnings, it can be used with many measurements. One measure of earnings quality is earnings persistence. Dechow and Schrand [2] explain that good earnings quality is when earnings are more persistent, more attached to future cash flows, and more attached to contemporary stock price performance. Perotti [3] states that earnings persistence shows whether current earnings will survive or repeat themselves in the future. High earnings persistence indicates a stable, sustainable profit so that it is increasingly useful in predicting future profits in a company.

So many cases that occur are committed by top management, so there are internal and external factors that can affect the quality of company earnings. One of the factors thought to affect earnings quality is the characteristics of top management. Boediono [4] states that the characteristics of top management are very influential on earnings disclosure, so that it can attract the trust of investors and shareholders. Hambrick and Mason [5] say that thetheory upper echelon assesses that the characteristics of top management are reasonable indicators to reflect differences from the psychological attributes of top management. In general, the characteristics of top management can be measured based on several factors, namely, tenure [6, 7], educational background [8] and gender [9]. These management characteristics will influence strategic 
Theresia Olivia \& Erna Setiany., Saudi J Bus Manag Stud, Apr, 2021; 6(4): 135-145

decision making such as earnings information to stakeholders in line with the echelon theory. Several studies that explain the influence of management characteristics on earnings quality include: Fatimah [6]; Vernando and Rakhman [7]; Krishnan L [9]. Other studies that explain the absence of the influence of management characteristics on earnings quality include: Dimitrova, 2017 [10]; Hutapea, 2019 [8]; Chairunesia, Sutra, and Wahyudi [11]. Thus there are still pros and cons that encourage this research to be interesting to research.

Another factor that is thought to affect earnings quality is Good Corporate Governance (GCG). Where the relevance of earnings is a means of measuring the company's financial performance, it is faced with managers' manipulation practices, so to reduce and prevent these harmful practices, a control mechanism is needed, namely corporate governance [12]. GCG is an effort that companies can make to increase company value to produce quality earnings while preventing the occurrence of earnings management carried out by the company, to increase investor confidence in the company's financial statements [13]. Where GCG disclosure includes principles such as the principles of transparency, accountability, responsibility, independence, fairness and equality [14].

In this study, Good Corporate Governance (GCG) is measured using the CG index where the CG index is the ranking of companies based on the level of implementation of Good Corporate Governance [15]. This index is expected to reflect comprehensive GCG in a company because it contains an assessment of various CG principles in BUMN, which will affect company performance [16].

Thus this study aims to provide empirical evidence of the influence of the characteristics of top management and GCG on earnings quality. This research's theoretical benefit is to add research references related to earnings quality when viewed from the characteristics of top management; currently, research for SOEs companies is still minimal. The benefits of practice for investors who buy shares of SOE companies make decisions based on earnings information. They must pay attention to management characteristics (top management) and fulfillment of the implementation of GCG in the company.

\section{LITERATURE REVIEW Agency Theory}

The agency theory explained asymmetric information between the principal (owners of capital) to the agent (management headed by directors) so that it appears the agency conflict or conflict of interest. Management will provide information beneficial to management, such as informing biased earnings to stakeholders [17, 18]. Thus, earnings information becomes unreliable for use in decision making considerations. This condition explains a low quality of earnings $[19,20]$.

\section{Upper Echelon Theory}

This theory was first introduced by Hambrick and Mason [5]. This theory explains that the characteristics of top management will be reflected in the decisions made [21]. Therefore, it is very important to understand the characteristics of decision makers before considering the results of these decisions in decision making. For example: the tenure of top management will determine their capabilities and experience in the field they are engaged in so that decisions taken are based on careful professional considerations. Likewise, the educational background of top management will influence knowledge formation in the industry and reflect decision making such as financial transparency. In addition, gender also psychologically will influence strategy setting and decision making.

\section{Earnings Quality}

Financial reports must have good quality information, including earnings information. Earnings information usually measures the success or failure of achieving a set goal over a certain period of time. Dichev et al., [22] defines earnings quality as a condition in which the profit is sustainable and is able to predict future earnings. Profit is said to be of quality when there is no gap between accruals and cash flows, or in other words, accruals can accurately reflect cash to be realized. Also, there is consistency in the selection of accounting policies in each report.

Meanwhile, Wahlen et al., [23] defines earnings quality as earnings that can be used to make an accurate assessment of current performance and can be used as a basis for predicting future performance. According to Dechow et al., [24] quality earnings are when (1) earnings information is relevant in decision making, (2) reported profit figures are sufficient to inform the company's financial condition, and (3) the accounting system is able to measure financial performance, so it is relevant between financial performance and decisions taken.

\section{Earnings Persistence}

Earnings persistence is a measure of earnings quality. Penman [25] said that the persistence of earnings revisions in accounting profit is expected in the future (expected future earnings) that is implied by the innovation profit for the year (current earnings). Meanwhile, according to Sunarto [26], earnings persistence is profit that has the ability as an indicator of future earnings generated by the company repetitively in the long term (sustainable). Profits are said to be persistent and can be used as a consideration for earnings quality, if current earnings can be used as a measure of future earnings [27]. In addition, profit is 
Theresia Olivia \& Erna Setiany., Saudi J Bus Manag Stud, Apr, 2021; 6(4): 135-145

said to be of quality if it can be reflected in the share price. This shows that the profit information is used by investors in making investment transactions.

\section{Characteristics of Top Management}

In this study the characteristics of top management using indicators: employment, educational background, and gender. According to Hambrick and Mason [5] by studying the characteristics of top management is very important because it will determine the company's performance, one of which will have an impact on the outcomes or higher quality company profits. The existence of characteristic variations in top management will provide various alternative ideas as a basis for making decisions so that the resulting outcomes are of higher quality.

\section{Tenure}

The tenure referred to in this study is the tenure of top management. The top management or president director position in the company averages 3-5 years if there is nothing that causes the director to be dismissed prematurely [28]. The working period can be related to a person's work experience, because with a long or long working period a person can have a lot of experience in their field of work. The longer the person's tenure, the more experienced a person is, so it is hoped that the quality of work provided will be better [29]. A new top management takes between three and five years to obtain an adequate understanding of the company to influence the decision- making process, which will ultimately affect the quality of existing earnings [30].

\section{Educational Background}

A board of directors can be qualified and competent in a field when viewed from the level of education taken and in what field of education a director has taken. According to Yuniarsih and Suwatno [31], education is an activity to improve a person's general knowledge, including increasing mastery of theory and skills in deciding on issues related to activities in achieving a goal. Chiang et al., [32] argue that top management is considered as people who have professional knowledge, experience, and abilities if they use professional skills and previous experience to help companies with various assistance and recommendations so as to improve the quality of the final result or profit company.

\section{Gender}

Fujianti [33] Gender can be defined as the differentiation of roles, attributes, attitudes, or behaviors, which grow and develop in society or are considered socially appropriate for men and women. Gender is often one of the personal characteristics that influence superiors in placing employees in certain types of work. When a woman reaches an executive position, the woman will work hard to maintain her position as an executive, and women will be honest. A woman director will strive to produce high company performance $[34,35]$.

This will affect the quality of earnings which is informed as management performance. The level of the number of women in top management positions more than the number of men will reduce the existence of earnings management, thereby increasing the quality of earnings.

\section{Implementation of Good Corporate Governance (GCG)}

Regulation of the Minister of State for SOEs No. PER-01 / MBU/ 2012, regarding the Implementation of SOEs, states that good corporate governance is the principles that underlie a process and mechanism for managing a company based on statutory regulations and business ethics. Good corporate governance can encourage directors and management to achieve goals that are the interests of the company, and shareholders must continue to carry out tighter supervision so that the company can ensure management works efficiently [14, 36, 37]. With the implementation of GCG carried out in SOEs, it is hoped that it will improve the earnings of quality. Implementation of good corporate governance is expected to control management to make reliable and reliable disclosures, including earnings disclosures, so that there is no bias for stakeholders who use this information in decision making [38].

In this study, good corporate governance (GCG) is measured using the CG index. This index is important because it contains a comprehensive assessment of the various principles of corporate governance in SOEs that will affect company performance. The $\mathrm{CG}$ index is usually used as a weighting of various indicators for the implementation of a company's CG. Kostyuk et al., [39] stated that measuring the quality of $\mathrm{CG}$ implementation can be evaluated by focusing on CG items that are considered substantially dominant. This study uses the CG index developed by researchers Nurharjanto et al., [16], based on input from many practitioners and academics who are experts in their respective fields.

\section{HYPOTHESIS \\ Tenure on Earnings Quality}

In generating earnings of quality, it is necessary to have the role of top management, who is, of course, quality. The quality of top management can be judged based on the characteristics of top management itself. The characteristics of top management can be assessed from many aspects, such as tenure. The longer the tenure of a person, the more experienced a person is, so it is hoped that the quality of work provided will be better [29].

So someone who has a tenure of between three and five years will have a deeper understanding of the 
Theresia Olivia \& Erna Setiany., Saudi J Bus Manag Stud, Apr, 2021; 6(4): 135-145

company so that it can influence the decision-making process, which will certainly affect the quality of existing earnings. Xiong's research [40] states that top management who has a long or long tenure has a positive effect on earnings management. This is also supported by research from Vernando and Rakhman [7], which states that there is a positive influence between tenure and earnings quality.

H1: Tenure an effect on the Earnings Quality

\section{Educational Background on Earnings Quality}

A top management person can be said to be qualified and competent in a field when seen from how high the level of education has been taken and what education has been taken by a top management. Chiang et al., [32] argue that top management is considered as people who have professional knowledge, experience, and abilities if they use their professional skills and previous experience to help companies with various assistance and recommendations, so as to improve the quality of the final result or profit. company. A high level of education among directors will result in a greater ability to adopt new ideas and accept innovations to increase company profits. Research by Hoang et al., [41] which states that board diversity as measured by the degree of top management educational has a positive effect on earnings quality. This is also supported by research by Xiong [40] which states that top management who has high educational has a positive effect on earnings management.

$\mathrm{H} 2$ : Educational Background an effect on the Earnings Quality

\section{Gender on Earnings Quality}

Then the characteristics of top management can also be measured by gender of top management. Gender is often one of the personal characteristics that influence superiors in placing employees in certain types of work. Women are often offered fewer career opportunities even with lower incomes. When a woman reaches a high position in a position, she will work hard to maintain her position as an executive. A woman top management will strive to produce high company performance.

This will affect the quality of earnings which is informed as management performance. The level of the number of women in top management positions more than the number of men will reduce the existence of earnings management, thereby increasing the quality of earnings.

Research by Al Azeez, Sukoharsono, Roekhudin, and Andayani [42] found that diversity gender has a significant impact on the reduction in earnings management. This is also supported by research by Hoang et al., [41] which states that board diversity as measured by the gender of top management has a positive effect on earnings quality.
H3: Gender especially women an effect on the Earnings Quality

\section{Implementation Good Corporate Governance on Earnings Quality}

For companies, the implementation of Corporate Governance in company activities is a solid foundation for realizing the company's vision and mission. Effendi [14] defines Good Corporate Governance as a system designed to direct corporate management in a professional manner based on the principles of transparency, accountability, responsibility, independence, fairness and equality. Rahayu [43] explains that the benefits of GCG for the company, both internal and external, are: (1) Facilitating the decisionmaking process, (2) Avoiding abuse of authority by the board of directors in managing the company; (3) Increase the value of the company in the eyes of investors; (4) Shareholders may increase share value \& increase dividend value; (5) Increase stakeholders' trust in the company, so that the company's positive image will increase; and (6) Improve the quality of the company's financial reports. Therefore, the existence of GCG principles implemented in SOEs is expected to improve the quality of earnings. Research from Siallagan [44] states that the GCG mechanism affects earnings quality.

H4: Implementation Good Corporate Governance (GCG) an effect on the Earnings Quality

Below is an overview of the framework used in assessing the phenomenon of earnings quality.

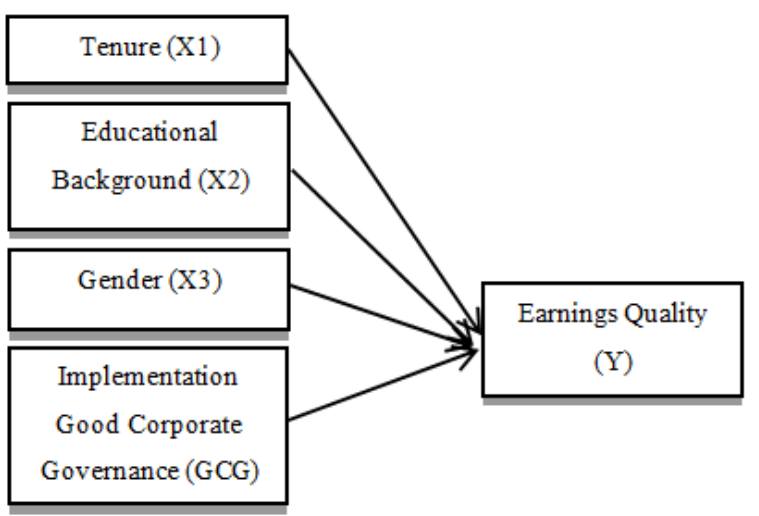

\section{RESEARCH METHODS}

This research is a quantitative study with 4 independent variables, namely tenure, educational background, gender and GCG which are tested on the dependent variable, namely earnings quality. The population in this study were 115 state-owned companies in Indonesia and used purposive sampling technique in taking the research sample. From the results of sample filtering, 67 companies were obtained in the 3-year observation period, namely 2016 to 2018. The total observation data was 201 data. The data source is from the website official SOEs 
Theresia Olivia \& Erna Setiany., Saudi J Bus Manag Stud, Apr, 2021; 6(4): 135-145

(www.bumn.go.id) to obtain the company's annual reports. Data collection techniques with literature and documentation studies. The analysis method used is Eviews.

Measurement of variables in this study using an ordinal scale. The operational variables along with the dimensions and indicators of each variable used in this study can be seen as follows:

\section{Earnings Quality (Y)}

This study uses earnings persistence as an indicator of the earnings quality variable [45].

ROAt $=\alpha \times$ ROAt $-1+3 t$

Information:

ROAt $\frac{\text { Net Income (The Current Yeny) }}{\text { Total Ascet (The Current Yeny) }} x 100 \%$

ROAt-1

$3 t$ Net Income on The Previous Year : $\frac{\text { Total Asset (The Previous Yenr?] }}{2} 100 \%$ : Error

\section{Tenure (X1)}

Fatimah (2019) explains that the measurements in the of the directors tenure are:

$\frac{T \text { op management with a tenure of more than } 3 \text { years }}{T \text { he total number of topmanagenent }} \times 100 \%$

\section{Educational Background (X2)}

Chiang, et al., [32] used a nominal scale measurement for educational background. If top

management has a background in business education, accounting or accounting and finance related professions, it is given a score of 1 and otherwise a score of 0

\section{Gender (X3)}

Kristianti [34] uses the measurement of the percentage of female top management to total top management in measuring the variable gender: Total female top management total top management $x 100 \%$

\section{Implementation Good Corporate Governance (GCG)} (X4)

In this study, GCG was measured using the CG index. Therefore this study uses the index Corporate Governance developed by researchers Nurharjanto et al., [16], based on input from many practitioners and academics who are experts in their respective fields.

Measuring the CG index can be done by weighting the $C G$ index in the annual report and adjusting it to the index in the research of Nurharjanto et al., [16] using a dummy scale (1 and 0), and assessing responses per item multiplied by the index weight value per item (index attached).

\section{RESULT}

Table-1: Descriptive Statistics Test

\begin{tabular}{|l|l|l|l|l|l|}
\hline \multicolumn{5}{|l|}{ Sample: 2016 2018 } \\
\hline & EQ & TEN_X1 & EBA_X2 & GEN_X3 & GCG_X4 \\
\hline Mean & -0.211146 & 0.372782 & 0.731928 & 0.090324 & 0.012590 \\
\hline Median & 0.021556 & 0.333333 & 0.750000 & 0.000000 & 0.012707 \\
\hline Maximum & 38.58275 & 1.000000 & 1.000000 & 0.800000 & 0.014263 \\
\hline Minimum & -44.72006 & 0.000000 & 0.000000 & 0.000000 & 0.008995 \\
\hline Std. Dev. & 6.314516 & 0.307339 & 0.224665 & 0.141547 & 0.001072 \\
\hline Observations & 201 & 201 & 201 & 201 & 201 \\
\hline
\end{tabular}

(Source: Data processed by Eviews 9, 2020)

Based on the results of the calculations in Table-1, it shows the descriptive statistics of the variables used in the study with the amount of data for each variable is 201 as follows:

a) In variable $Y$, which is the persistence of earnings to measure earnings quality, has an average value of - 0.211146, a maximum value of 38.58275 obtained from the company PT Barata Indonesia, the minimum value obtained is -44.72006 obtained from PT Asuransi Jasa Indonesia. With a standard deviation of 6.314516 , it shows the variations in the value of earnings quality, and the median value is 0.021556 .

b) Based on the measurement of descriptive statistics, it shows that the results in the table can be seen for tenure (TEN), it is explained that a minimum value of 0,000 and a maximum value of 1,000 explains the existence of a company whose overall top management has a tenure as directors of less than 3 years and number 1 shows that all directors have tenure greater than 3 years. The max value shows the number 1,000 contained in 15 companies, one of which is PT Asuransi Kerugian Jasa Raharja, this value can be interpreted that the total number of directors in a company has exceeded the tenure of $\geq 3$ years because this is obtained by dividing the number of directors who have worked $\geq 3$ years with a total of directors. So if an example is given in a company there are three directors and all three of them have exceeded the 3-year tenure, then three will be divided by three so that the number 1 will be obtained. While 0,000 is like the min value obtained from 20 companies, one of which is PT Bhanda Ghara Reksa, this value means that none of the directors has exceeded 3 years of service in the company because, for example, 0 divided by the 
total number of directors will show the number 0 . However, the average length of tenure shows a value of 0.373 which means, for example, if there are 3 directors in the company, 1 of them is certain. has a tenure of more than 3 years and 2 other directors under 3 years.

c) For the educational background variable (EBA) it is the one that influences the quality of earnings where it appears in the table that the maximum value that is owned is 1,000 which is found in 23 companies, one of which is PT Pembangunan Pariwisata Indonesia, this value can be interpreted that the total number of top management in a company who have a background in business education, accounting or accounting and finance related professions because this is obtained by dividing the number of directors with backgrounds according to the specified criteria by the total number of directors in the company. However, seen from table 1, EBA obtains a minimum value of 0.000 which is found in 3 sample companies, one of which is PT Industri Kereta Api (Inka), this value reflects that there are companies whose entire directors do not have a business background, accounting or take accounting-related professions. However, on average, the educational background (EBA) shows a value of 0.732 which means that almost all top management or $73.2 \%$ in companies, especially SOEs, have an educational background by the specified criteria.

d) For variable gender from the top management to a maximum of 0.800 shows that in getting from one company, PT Sarinah, this value means that there is an $80 \%$ state-owned company top management is female. For a minimum value of 0.000 obtained from 46 companies, PT Adhi Karya explains that there are SOEs companies where there are absolutely no women in the top management. On average, the gender shows a value of 0.090 which means that as many as $9.03 \%$ of all SOEs companies have female directors leading a company; men rule the rest. This opens a new research discourse, why women do not hold any directorships in SOEs. Meanwhile, the gender of the board of directors will psychologically influence decisions, including earnings information.

e) Henceforth, the variable good corporate governance (GCG) can be seen from the table explaining that the number 0.014 or $1.4 \%$ in the maximum value shown from 13 companies, one of which is PT Garuda Indonesia, Tbk. and means that only $1.4 \%$ of state- owned companies have implemented GCG correctly and by the established rules regarding GCG. For a minimum value of 0.009 or $0.9 \%$ obtained from 2 companies, PT Dahana is explaining that there are state-owned companies that do not implement GCG at all or apply but are not by the established GCG rules. However, on average, only 0.013 or $1.3 \%$ of all state-owned companies have implemented GCG in the company properly and are by the GCG rules that the government has set.

\section{Panel Data Regression Analysis Chow Test}

Based on this study's test results, the F-value test obtained is 0.0149 , which is smaller than $\alpha=0.05$ (5\%). So that $\mathrm{H} 0$ is not supported, and $\mathrm{H} 1$ is accepted, which means that the model used in this study is the fixed effect model.

\section{Hausman Test}

Based on this study's test results, the probability value Chi- Square obtained is $0.0042<$ from $\alpha=0.05(5 \%)$. So, because the probability Chi-Square < $0.05, \mathrm{H} 0$ is not supported while $\mathrm{H} 1$ is accepted, which means the model used in this study is the fixed effect model.

\section{Lagrange Multiplier Test}

Based on this study's test results, the probability value Chi- Square obtained is $0.9488>$ from $\alpha=0.05(5 \%)$. H0 is not supported while $\mathrm{H} 1$ is accepted, which means that the best model in this study is the common effect model.

Classic assumption test Table 2: Normality Test
\begin{tabular}{|l|l|l|}
\hline Long-run Normality Test \\
\hline Date: 03/22/21 Time: $19: 03$ \\
\hline Sample: 2016 2018 \\
\hline Included observations: 201 \\
\hline & Statistic & Prob. \\
\hline Skewness & -0.681586 & 0.752250 \\
\hline Kurtosis & 2.055954 & 0.019893 \\
\hline Normality & 4.769755 & 0.092100 \\
\hline
\end{tabular}

(Source: Data processed by Eviews 9, 2020)

Based on the results of the tests that have been carried out in this study, it is known that the significant value $0.092100>\alpha 0.05$. So it can be concluded that the data is normally distributed.

Table-3: Multicollinearity Test

\begin{tabular}{|l|l|}
\hline Variable & VIF \\
\hline TEN_X1 & 1.075973 \\
\hline EBA_X2 & 1.086927 \\
\hline GEN_X3 & 1.032873 \\
\hline GCG_X4 & 1.096200 \\
\hline
\end{tabular}

(Source: Data processed by Eviews 9, 2020)

Based on the results of the tests that have been carried out, it is known that the VIF value is 0.8 . VIF value $<10$, it can be concluded that there is no correlation between independent variables. 
Theresia Olivia \& Erna Setiany., Saudi J Bus Manag Stud, Apr, 2021; 6(4): 135-145

Table-4: Heteroscedasticity Test

\begin{tabular}{|l|c|l|l|}
\hline \multicolumn{4}{|l|}{ Heteroskedasticity Test: White } \\
\hline F-statistic & 0.208184 & Prob. F(14,186) & 0.9991 \\
\hline Obs*R-squared & 3.101029 & Prob. Chi-Square(14) & 0.9989 \\
\hline Scaled explained SS & 45.21660 & Prob. Chi-Square(14) & 0.0000 \\
\hline
\end{tabular}

(Source: Data processed by Eviews 9, 2020)

Based on the test results, it can be seen that the value of prob. equal to 0.0000 and less than 0.05 . So that the SOEs company data can be concluded that there is no heteroscedasticity.

Table-5: Non-Autocorrelation Assumptions

\begin{tabular}{|l|l|l|l|}
\hline \multicolumn{5}{|l|}{ Breusch-Godfrey Serial Correlation LM Test: } \\
\hline F-statistic & 1.636064 & Prob. F(2,194) & 0.1974 \\
\hline Obs*R-squared & 3.333962 & Prob. Chi-Square(2) & 0.1888 \\
\hline
\end{tabular}

(Source: Data processed by Eviews 9, 2020)

Based on the test results, it can be seen that the significant value of Chi-Squared (2) is $0.1888>\alpha 0.05$; it can be concluded that the model is not free of autocorrelation

\section{Table-6: Linearity Test}

\begin{tabular}{|c|c|c|c|}
\hline \multicolumn{4}{|c|}{ Ramsey RESET Test } \\
\hline \multicolumn{4}{|c|}{ Equation: UNTITLED } \\
\hline \multicolumn{4}{|c|}{ Specification: EQ C TEN_X1 EBA_X2 GEN_X3 GCG_X4 } \\
\hline \multicolumn{4}{|c|}{ Omitted Variables: Powers of fitted values from 2 to 3} \\
\hline & Value & df & Probability \\
\hline F-statistic & 1.324858 & $(2,194)$ & 0.2682 \\
\hline Likelihood ratio & 2.726744 & 2 & 0.2558 \\
\hline
\end{tabular}

(Source: Data processed by Eviews 9, 2020)

Based on the table, there is an F-value statistic of $0.2558>\alpha 0.05$. So it can be concluded that the model is linear.

\section{Hypothesis testing}

Table-7: Model Regression Results

\begin{tabular}{|c|c|c|c|c|c|}
\hline $\begin{array}{l}\text { Dependent Variable: } \\
\text { Method: Panel EGLS } \\
\text { Sample: } 20162018 \\
\text { Periods included: } 3 \\
\text { Cross-sections includ } \\
\text { Total panel (balanced } \\
\text { Linear estimation afte } \\
\text { White cross-section s }\end{array}$ & $\begin{array}{l}\text { EQ } \\
\text { (Cross-sectio } \\
\text { ed: } 67 \\
\text { observation } \\
\text { one-step we } \\
\text { andard errors }\end{array}$ & $\begin{array}{l}\text { weights) } \\
\text { : } 201 \\
\text { ighting matri } \\
\& \text { covariano }\end{array}$ & 更 & cted) & \\
\hline Variable & Coefficient & Std. Error & t-Statistic & Prob. & Conclusion \\
\hline C & -4.041976 & 1.301395 & -3.105880 & 0.0023 & \\
\hline TEN_X1 & -2.186404 & 0.175726 & -12.44211 & 0.0000 & Reject $\mathrm{H}_{0}$ Significant Negative \\
\hline EBA_X2 & 2.058005 & 0.305815 & 6.729585 & 0.0000 & Reject $\mathrm{H}_{0}$ Significant Positive \\
\hline GEN_X3 & 1.787244 & 0.388323 & 4.602466 & 0.0000 & Reject $\mathrm{H}_{0}$ Significant Positive \\
\hline GCG_X4 & 372.0021 & 119.8736 & 3.103287 & 0.0023 & Reject $\mathrm{H}_{0}$ Significant Positive \\
\hline & Effects Spe & cification & & & \\
\hline Cross-section fixed (c & ummy variabl & es) & & & \\
\hline & Weighted $\subseteq$ & tatistics & & & \\
\hline $\begin{array}{l}\text { R-squared } \\
\text { Adjusted R-squared } \\
\text { S.E. of regression } \\
\text { F-statistic } \\
\text { Prob(F-statistic) }\end{array}$ & $\begin{array}{l}0.616830 \\
0.410508 \\
5.560484 \\
2.989645 \\
0.000000\end{array}$ & $\begin{array}{l}\text { Mean depe } \\
\text { S.D. depen } \\
\text { Sum squar }\end{array}$ & $\begin{array}{l}\text { ndent var - } \\
\text { dent var } \\
\text { ed resid }\end{array}$ & $\begin{array}{l}-0.367919 \\
7.240795 \\
4019.468\end{array}$ & \\
\hline
\end{tabular}

(Source: Data processed by Eviews 9, 2020)

$Y=-3.105880-12.44211 * X 1+6.729585 * X 2+4.602466 * X 3+3.103287 * X 4+e$ 
Theresia Olivia \& Erna Setiany., Saudi J Bus Manag Stud, Apr, 2021; 6(4): 135-145

Adjusted $\mathbf{R}^{2}$ Test

The R-Squared value in this study based on the test results was 0.616830, which means that all independent variables in the model were able to explain variations and contribute to dependent variables by $61.68 \%$. In comparison, the remaining $38.32 \%$ were other independent variables that researchers did not examine.

\section{F Test}

In this study, the results of the $\mathrm{F}$ test show that the $\mathrm{P}$ - value is $0.0000<0.05$, which means that $\mathrm{H}_{0}$ is not supported, and it is concluded that with an error rate of $5 \%$, the model is fit or appropriate, in other words, together the independent variables affect the variable linearly significantly dependent.

\section{T-Test}

From the results of the regression model, it can be seen that the variables that have a significant positive effect on the Earning Quality variable are Educational Background (EBA), Gender (GEN), and Good Corporate Governance (GCG). Meanwhile, the tenure variable (TEN) has a negative effect on earnings quality.

a) Effect of Tenure on Earnings Quality. Whereas the coefficient of tenure is -2.186 , every increase of the 1 percent working period variable will reduce the earnings quality variable by 2.186 percent, assuming other variables are constant. The value probability is TEN 0.000 or less than $\alpha=0.05$ so that $\mathrm{H} 0$ is not supported and $\mathrm{H} 1$ is accepted, which means that tenure (TEN) has a partially negative and significant effect on earnings quality.

b) Effect of Educational Background on Earnings Quality. That the coefficient of educational background is 2.058 means that every increase of 1 percent of the background variable will increase the earnings quality variable by 2.058 percent, assuming other variables are constant. The value probability is EBA 0.000 or less than $\alpha=0.05$ so that $\mathrm{H} 0$ is not supported and $\mathrm{H}_{2}$ is accepted, which means that educational background (EBA) has a positive and partially significant effect on earnings quality.

c) Effect of Gender on Earnings Quality. That the coefficient of gender is 1.787 means that every 1 percent increase in the gender variable, especially women, will increase the earnings quality variable by 1.787 percent, assuming other variables are constant. The value probability is GEN 0.000 or less than $\alpha=0.05$ so that $\mathrm{H}_{0}$ is not supported and $\mathrm{H}_{3}$ is accepted, which means that gender (GEN) has a positive and partially significant effect on earnings quality.

d) Effect of Good Corporate Governance (GCG) on Earnings Quality. That the coefficient of good corporate governance is 372.002 means that every 1 percent increase in the GCG variable will increase the earnings quality variable by 372.002 percent, assuming other variables are constant. The value probability is GCG 0.002 or less than $\alpha=0.05$ so that $\mathrm{H} 0$ is not supported and $\mathrm{H} 4$ is accepted, which means that good corporate governance (GCG) has a positive and partially significant effect on earnings quality.

\section{DISCUSSION \\ The Effect of Tenure on Earnings Quality}

The results of this study have a negative effect on earnings quality. Top management with a tenure of more than three years tends to be brave enough to do earnings management. Meanwhile, new top management takes approximately three years to understand the company. It will be difficult for new top management to play with earnings and make earnings appear quality. Top management with a tenure of more than three years is sufficient knowledge to carry out earnings management in the company to make the quality of the earnings presented to be of poor quality. Top management who have served for a long time or for a long time tend to maintain their position in their position because by having a high place and doing for a long time, they significantly influence the policies that the company will take. The tenure of top management can show the experience of top management in managing a company. These results are in line with the research of Fatimah [6], Zwageri [46], and Zwageri, Roekhudin, and Rahman [47], but not in line with research conducted by Vernando and Rakhman [7], Xiong [40], Ali and Zhang [48], and Nugroho and Eko [49].

\section{The Effect of Educational Backgroud on Earnings Quality}

The results of this study have a positive effect on earnings quality. The higher the top management education, the higher the top management's ability to analyze, solve a problem and lead the company. Top management does not only need technical knowledge, but theoretical knowledge is also essential. Technical and theoretical knowledge must go hand in hand in leading a company, where specialized knowledge is obtained from the world of practice. In contrast, theoretical knowledge is obtained from education taken by top management. Therefore, the higher the top management education, the quality of the earnings generated will also be good because top management who has higher education must have a strategy that is by the theory studied without having to commit fraudulent actions such as earnings management which will worsen the action taken later. Reputation as top management. These results are in line with research conducted by Hoang et al., [41], Xiong [40], and Wang et al., [50], but contrary to study conducted by Hutapea [8], Pratomo and Hapsari [51], Aritonang [52], and Zwageri, Roekhudin, and Rahman [46]. 
Theresia Olivia \& Erna Setiany., Saudi J Bus Manag Stud, Apr, 2021; 6(4): 135-145

\section{The Effect of Gender on Earnings Quality}

The results of this study have a positive effect on earnings quality. The increasing number of women who hold positions in top management, especially in SOEs, will make the profit in a financial report more qualified. This is because women are more likely to avoid the risks involved if they commit a fraudulent act, such as earnings management. After all, it will have an impact on their reputation as top management. Therefore, women are more likely to carry out their duties by existing rules and their capacity as top management. So that earnings information reported to stakeholders is by the facts without any element of fraud. This result is in line with the research of Krishnan and L [9], Hoang et al., [41], and Al Azeez, Sukoharsono, Roekhudin, \& Andayani [42], but contrary to research conducted by Dimitrova [10], Kristanti [34], Hashim, Ahmed, and Huey [53], Rusmianto and Irawan [54].

\section{The Effect of Good Corporate Governance on Earnings Quality}

The results of this study have a positive effect on earnings quality. The higher the GCG index in a state- owned company, the higher the quality of reported earnings. This is by agency theory where there is a separation between the agent and the principal, which will result in a conflict of interest, which can affect the quality of reported earnings so that in these conditions, a control mechanism is needed that can align the interests of the two parties. Good corporate governance (GCG) is a tool that can be used as a reference in evaluating a company by investors, where the presence of GCG can increase investor confidence in a company. The higher the implementation of good corporate governance, the higher the level of company compliance with good company profitability and improving earnings quality. By implementing GCG in the company, it can minimize earnings management carried out by top management so that it will improve the performance of top management in a company. These results are in line with research conducted by Siallagan [44], Wicaksono and Rahmawati [55], and Marsela and Maryono [56]. However, this research is not in line with research conducted by Saifuddin [38], Chairunesia, Sutra, and Wahyudi [11], and Indriastuti [57].

\section{CONCLUSION}

1. Tenure has a significant negative effect on earnings quality. This means that top management with a tenure of more than 3 years tends to be brave enough to do earnings management. Meanwhile, a new top management takes approximately three years to gain sufficient understanding of the company so that it will be difficult for new top management to play with earnings and make earnings appear to be of quality.

2. Educational background has a significant positive effect on earnings quality. This means that the higher the education possessed by top management, the higher the ability of a top management to analyze, solve a problem and have a strategy in leading the company so that it can make quality earnings.

3. Gender has a significant positive effect on earnings quality. This means that the increasing number of women who occupy positions in top management, especially in SOEs, will make earnings in a financial report more qualified because women are more likely to avoid the risks that exist if they commit fraudulent acts such as earnings management because it will have an impact on their reputation as a person top management that he has achieved.

4. Good corporate governance (GCG) has a significant positive effect on earnings quality. This means that the higher the GCG index in a SOEs company, the quality of reported earnings will be high because Good corporate governance (GCG) is a tool that can be used as a reference in assessing a company by investors, where GCG can increase investor confidence in a company. The higher the implementation of good corporate governance, the higher the level of company compliance with good company profitability and the ability to improve earnings quality.

\section{SUGGESTION}

1. The next research is expected to add other variables that are not included in this research, such as company value which is a measurement of market performance and profitability which is a measurement of financial performance. As well as adding the research period so that more and more company data can be sampled to increase the validity of the results and stronger conclusions.

2. For the next research, it is expected to be able to use a sample of companies other than SOEs in order to know the quality of earnings when viewed from the side of sector companies outside of SOEs.

3. Prospective investors are expected to be able to help investors and potential investors who analyze the quality of earnings in companies to make investment decisions.

4. The company is expected to be more careful in presenting financial reports to investors or stakeholders, especially regarding existing earnings information because if it is wrong in presenting information on performance earnings from top management it will be questionable and of course it will make the reputation of the company decrease, especially in the eyes of the public. so that the company will no longer be trusted by either investors or the public.

\section{REFERENCES}

1. Wulansari, Y. (2013). Pengaruh Investment Opportuny Set, Likuiditas dan Leverage Terhadap Kualitas Laba pada Perusahaan Manufaktur yang 
Terdaftar di BEI. Jurnal Akuntansi, Vol 1, No 2.

2. Dechow, P., \& Schrand, C. (2004). "Earnings Quality". Research Foundation of CFA Institute. USA.

3. Perotti, P., Wagenhofer, A. (2014). Earning Quality Measures and Excess Returns. Journal of Business Finance \& Accounting, 41(5)\&(6):545-571.

4. Boediono, G. S. (2005). Kualitas Laba: Studi Pengaruh Mekanisme Corporate Governance dan Dampak Manajemen Laba Dengan Menggunakan Analisis Jalur. SNA (Simposium Nasional Akuntansi) VIII, (pp. 172-194). Solo.

5. Hambrick, D. C., \& Mason, P. A. (1984). Upper Echelons: The Organization as a Reflection of Its Top Managers. Academy of Management Review, Vol. 9, No. 2, 193-206.

6. Fatimah, D. (2019). Pengaruh Board Diversity Terhadap Manajemen Laba. Journal of Applied Accounting and Taxation, Vol. 4, No.2, E-ISSN : 2548-9925, 223-233.

7. Vernando, A., \& Rakhman, F. (2018). Masa Kerja CEO dan Manajemen Laba (CEO Tenure and Earnings Management). Jurnal Akuntansi dan Keuangan Indonesia, Vol. 15, No. 2, 201-215.

8. Hutapea, H. (2019). Pengaruh Corporate Governance dan Corporate Social Responsibility terhadap Kualitas Laba dan Nilai Perusahaan. Journal of Applied Accounting and Taxation, Vol. 4, No. 1, e- ISSN: 2548-9925, 79-86.

9. Krishnan, G. V., \& L., M. P. (2008). Getting to Bottom Line: An Exploration of Gender and Earnings Quality. Journal of Business Ethics, Vol. 78, 65-76.

10. Dimitrova, D. (2017). The Impact of Social Ties and Gender Diversity on Earnings Quality. Thesis in Corporate Finance and Control.

11. Chairunesia, W., Sutra, P. R., \& Wahyudi, S. M. (2018). Pengaruh Good Corporate Governance dan Financial Distress Terhadap Manajemen Laba pada Perusahaan Indonesia yang Masuk Dalam Asean Corporate Governance Scorecard. Profita: Komunikasi Ilmiah Akuntansi dan Perpajakan, Vol. 11 No. 2, p-ISSN: 2086-7662, e-ISSN: 2622-1950.

12. Harnovinsah, H. (2012). The Influence of Audit Committee Quality, Board of Commissioner's Quality, Institutional Ownerships, Management Ownerships Toward Earnings Management Practice and Financial Performance and the Implication Toward the Firm Value (Survey on the Go-public Companies Listed in the Indonesian Stock Exchange). Akuntabilitas : Jurnal Penelitian dan Pengembangan Akutansi, 6(2), 47-75.

13. Budianto, R., Samrotun, Y. C., \& Suhendro. (2018). Pengaruh Good Coporate Governance (GCG) Terhadap Kualitas Laba pada Perusahaan Manufaktur yang Terdaftar di BEI 2015-2017. Seminar Nasional dan Call for Paper : Manajemen, Akuntansi, dan Perbankkan, 411-424.

14. Effendi, M. A. (2016). The Power of Good Corporate Governance (e2). Jakarta: Salemba Empat.

15. Widarwati, E., \& Mulyawati, S. (2015). Peringkat Score Good Corporate Govern-ance dan Hubungannya Dengan Return Saham. Jurnal Analisis
Bisnis Ekonomi, 13 (1), 66-73.

16. Nurharjanto, Haryono, T., Suhardjanto, D., Lukviarman, N., \& Setiany, E. (2018). Corporate Governance, Privatisation, and Financial Performance of Indonesian State-Owned Enterprises. International Journal of Revenue Management, vol. 10, No 2, 168 188.

17. Ng, S., \& Daromes, F. E. (2016). Peran Kemampuan Manajerial Sebagai Mekanisme Peningkatan Kualitas Laba dan Nilai Perusahaan (The Role of Managerial Ability as a Mechanism to Improve Earnings Quality and Firm Value). Jurnal Akuntansi dan Keuangan Indonesia, Vol. 13, No. 2, 174-193.

18. Dira, Kadek Prawisanti dan Ida Bagus Putra Astika. (2014). Pengaruh Struktur Modal, Likuiditas, Pertumbuhan Laba, dan Ukuran Perusahaan pada Kualitas Laba. Jurnal Akuntansi Universitas Udayana, Vol. 7, No. 1: 64-78.

19. Triwahyuni, N. (2017). Pengaruh Kecakapan Manajerial Terhadap Kualitas Akrual (Studi Empiris pada Perusahaan Sektor Utama yang Terdaftar pada Bursa Efek Indonesia Tahun 2010-2014). Artikel Akuntansi Universitas Negeri Padang.

20. Tandiontong, Mathius. 2016. Kualitas Audit Dan Pengukurannya. Alfabeta, Bandung.

21. Lestari, P., D., \& Faisal, F. (2019). Hubungan Managerial Overconfidence, Kepenilikan Pemerintah dan Keputusan Pembiayaan Perusahaan. EKOBIS, Vol. 20, No. 2, 72-86.

22. Dichev, I., Graham, J., Harvey, C. R., \& Rajgopal, S. (2016). The Misrepresentation of Earnings. Financial Analysts Journal, Volume 72, No. 1, 22-35.

23. Wahlen, J. M., Baginski, S. P., \& Bradshaw, M. T. (2015). Financial Reporting, Financial Statement Analysis, and Valuation. 8th Edition. United States of America: Cengage Learning.

24. Dechow, P., Ge, W., \& Schrand, C. (2010). Understanding Earnings Quality: A Review of the Proxies, their Determinants and their Consequences. Journal of Accounting and Economics 50, 344-401.

25. Penman, Stephen H. Financial Statement Analysis and Security Valuation. Singapore: Mc Graw Hill., 2001.

26. Sunarto, (2010), Peran Persistensi Laba Terhadap Hubungan Antara Keagresifan Laba dan Biaya Ekuitas. Kajian Akuntansi, Vol. 2 No. 1, ISSN : 19794886, 22-38.

27. Suwandika, I Made Andi dan Ida Bagus Putra Astika. 2013. Pengaruh Perbedaan Laba akuntansi, Laba Fiskal, Tingkat Hutang Pada Persistensi Laba. EJurnal Akuntansi Universitas Udayana, Vol. 5.1, hal. 196-214.

28. Muniroh, H. (2016). President Director Tenure and Earnings Management. Jurnal Akuntansi Indonesia, Vol. 5 No. 2, 149-162.

29. Charolina, O., Husaini, \& Abdullah. (2013). Pengaruh Implementasi Pengeolaan Keuangan dan Pengalaman Kerja Terhadap Kualitas Laporan Keuangan Komisi Pemilihan Umum. Jurnal Fairness Volume 3, Nomor 3, 82-94.

30. Kesner, I. F. (1988). Directors' Characteristics and Committee Membership: An Investigation of Type, Occupation, Tenure and Gender. Academy of 
Managemet Journal Vol.31.

31. Yuniarsih, T., \& Suwatno. (2016). Manajemen Sumber Daya Manusia, Ed. 5. Bandung: Alfabeta.

32. Chiang, H. T., Lin, S. L., He, L. J., \& Sung, Y. T. (2016). Professional Education Background and Earnings Management of Chairmen and Senior Managers. The International Journal of Business and Finance Research, Vol. 10, No. 2, ISSN: 2157-0698, 91-108.

33. Fujianti, L. (2018). Top Management Characteristics and Company Performance: An Empirical Analysis on Public Companies Listed in the Indonesian Stock Exchange. European Research Studies Journal, Volume XXI, Issue 2, 62-76.

34. Kristanti, P. (2010). Tingkat Variasi Gender Posisi Manajemen Puncak dan Kualitas Laba Perusahaan. Jurnal Riset Akuntansi dan Keuangan, Vol. 6, No. 2, 87-98.

35. Kusumastuti, S., Supatmi, \& Sastra, P. (2007). Pengaruh Board Diversity Terhadap Nilai Perusahaan dalam Perspektif Corporate Governance. Jurnal Akuntansi dan Keuangan, Vol. 9, No. 2, 88-98.

36. IAI. (2015). Etika Profesi dan Tata Kelola Korporat. Jakarta.

37. Labesi, T. M. (2013). Analisis Penerapan PrinsipPrinsip Good Corporate Governance di PT Bank Sulut Kantor Pusat Manado. Jurnal EMBA: Jurnal Riset Ekonomi, Manajemen, Bisnis dan Akuntansi, Vol. 1, No. 4, ISSN : 2303-1174, 1274-1283.

38. Saifuddin, W. (2016). Pengaruh Good Corporate Governance (GCG) dan Struktur Kepemilikan Terhadap Kualitas Laba dengan Konvergensi IFRS Sebagai Variabel Mediasi. Artikel Ilmiah Sekolah Tinggi Ilmu Ekonomi PERBANAS Surabaya, 1-17.

39. Kostyuk, A., Gerner-Beuerle, C. and Apreda, R. (2011) Corporate Governance: An International Outlook, Virtus Interpress.

40. Xiong, J. (2016). Chairman Characteristics and Earnings Management: Evidence from Chinese Listed Firms. Open Journal of Accounting, 5, ISSN Online: 2169-3412, ISSN Print: 2169-3404, 82-94.

41. Hoang, T. C., Abeysekera, I., \& Ma, S. (2016). The Effect of Board Diversity on Earnings Quality: An Empirical Study of Listed Firms in Vietnam. Australian Accounting Review, 1-18.

42. Al Azeez, H. A., Sukoharsono, E. G., Roekhudin, \& Andayani, W. (2019). The Impact of Board Characteristic on Earnings Management in the International Oil and Gas Corporations. Academy of Accounting and Financial Studies Journal, Volume 23, Issue 1, 1-26.

43. Rahayu, A. A. (2013). Pengaruh Good Corporate Governance Terhadap Kinerja Keuangan PT. Telekomunikasi Indonesia Berdasarkan Penilaian Indonesia Institute of Corporate Governance. Jurnal Akuntansi Unesa, 1(3).

44. Siallagan, H. (2007). Pengaruh Mekanisme Corporate
Governance Terhadap Kualitas Laba. Jurnal Widya Manajemen \& Akuntansi, 7(1), 1-14.

45. Sloan, R. (1996) Do stock prices fully reflect information in accruals and cash flows about future earnings? Accounting Rev. 71:289-315.

46. Zwageri, A., Roekhudin, R., \& Rahman, A. F. (2020). The Effect of Top Management Team Characteristics to Earning Management. International Journal of Multicultural and Multireligious Understanding, 7(8), 124-137.

47. Zwageri, A., Roekhudin, R., \& Rahman, A. F. (2020). The Effect of Top Management Team Characteristics to Earning Management. International Journal of Multicultural and Multireligious Understanding, 7(8), 124-137.

48. Ali, A., \& Zhang, W. (2015). CEO tenure and earnings management. Journal of Accounting and Economics, 59(1), 60-79.

49. Nugroho, P. E. (2011). Rancang Bangun Turbin Angin Sumbu Vertikal Mikro Wind Energy Skala Rumah Tangga (Doctoral dissertation, Universitas Muhammadiyah Surakarta).

50. Wang, M., Audi, G., Kondev, F. G., Huang, W. J., Naimi, S., \& Xu, X. (2017). The AME2016 atomic mass evaluation (II). Tables, graphs and references. Chinese Physics C, 41(3), 030003.

51. Pratomo, D., \& Hapsari, D. W. (2018). The Role Of The Board Of Commissioners In Earnings Management. Sustainable Collaboration in Business, Technology, Information and Innovation (SCBTII), 1(1).

52. Aritonang, J. (2018). Analisis Formularium RSUD Cimacan Tahun 2017. Jurnal Administrasi Rumah Sakit Indonesia, 3(2).

53. Hashim, F., Ahmed, E. R., \& Huey, Y. M. (2019). Board Diversity and Earning Quality: Examining the Role of Internal Audit as a Moderator. Australasian Accounting, Business and Finance Journal, 13(4), 7391.

54. Rusmianto, R., \& Irawan, I. (2016). Determinan Kulitas Laba di Indonesia Studi Empiris pada Perusahaan yang Mempublik di Bursa Efek Indonesia. Jurnal Ilmiah ESAI, 10(1), 22-33.

55. Wicaksono, A. S., \& Rahmawati, I. P. (2019). Pengaruh Kecakapan Manajerial, Good Corporate Governance Dan Book Tax Differences Terhadap Kualitas Laba Perbankan Di Indonesia. Jurnal Mutiara Madani, Volume 07 No. 2, 161-179.

56. Marsela, S. Y., \& Maryono, M. (2017). Pengaruh Good Corporate Governance, Leverage, Profitabilitas Dan Ukuran Perusahaan Terhadap Kualitas Laba (Studi pada Perusahaan Publik yang Termasuk Dalam Pemeringkatan CGPI Tahun 2013-2016). Dinamika Akuntansi Keuangan dan Perbankan, 6(1).

57. Indriastuti, M. (2014). Kolerasi Penerapan PrinsipPrinsip Corporate Governance Dengan Manajemen Laba. Jurnal Ekonomi dan Bisnis, 15(1), 51-61. 